\title{
The Southern Bug - Dnister Interfluve During World War II: Administrative Organization, Staffing and Statistics
}

\author{
Mykola Mykhailutsa' 1 , Igor Niculcea² 10
}

'Corresponding author/Sorumlu yazar: Mykola Mykhailutsa (Prof. Dr.), Odessa National Maritime University, Head of the Department of Ukrainian Studies, Historical and Legal Disciplines and Linguistic Disciplines, Odessa, Ukraine. E-posta: michailuca@ukr.net ORCID: 0000-0003-4896-0580

${ }^{2}$ Igor Niculcea (Research Fellow), State University of Moldova, Center for Study of Totalitarian Regimes \& Cold War, Kishinev Moldova.

E-posta: Ingvarnik@gmail.com ORCID: 0000-0000-0000-0000

Submitted/Başvuru: 14.09.2020 Revision Requested/Revizyon Talebi: 15.11.2020

Last Revision Received/Son Revizyon: 17.11.2020

Accepted/Kabul: 01.01.2021

Citation/Atıf: Mykhailutsa, Mykola and Niculcea, Igor, "The Southern Bug Dnister Interfluve During World War II: Administrative Organization, Staffing and Statistics", Güneydoğu Avrupa Araştırmaları Dergisi, 35 (2020), s. 189-205.

https://doi.org/10.26650/gaad.794916

\section{ABSTRACT}

The article presents a modern view of the administrative and territorial component of the occupation policy of Romania in the Ukrainian lands between the Dniester and Southern Bug during World War II. This territory called the Transnistria Governorate was a specific delimitation of the military and political interests of the warring countries - Romania, Germany, the Union of Soviet Socialist Republics (USSR), which determined the structural changes in the territorial and administrative plan. Based on a wide range of important documents from the archives of Romania, Moldova, and the south of Ukraine, using various methods, including the quantitative method, the authors presented the administrative structure of the governorate and statistics on the staffing of the occupation system by the functionaries in the ratio: the locals and the occupiers.

Keywords: World War li, Transnistria, Occupation, South of Ukraine, Administrative Structure 
A decade ago, the problem that we actualized remained far beyond the limits of the research epicenter which mainly stimulated a scientific discourse around the topic of the Nazi politics of the Third Reich in Eastern Europe from 1930 to 1945 among academics concerned. At the same time, the problems of the administrative structure and the essential characteristics of the occupation policy of one of Germany's allies in World War II - authoritarian Romania, remained terra incognita in Ukrainian historiography until the very beginning of this millennium. And if in Romania itself, and partly in Moldova, for a quarter of a century, there was a sharp confrontation between the old, conservative adherents of the idea of "Greater Romania" on the one hand, and young, progressive modernist scientists (J.Ancel ${ }^{1}$, A.Golopentia $^{2}$, A.Moraru $^{3}$, A.Petrencu ${ }^{4}$, R.Solovei ${ }^{5}, 0$. Verenca $^{6}$ and others) on the other hand, in Ukraine it became possible to implement scientific plans in this direction only after the declaration of independence. To a certain extent, this was facilitated by the intermingling of several factors, the importance of which can hardly be overestimated: it was at the beginning of the 1990s, when previously closed archival files of the World War II period, the so-called "occupation" ones, were opened for researchers (in the Union of Soviet Socialist Republics (USSR) these funds were not made public for mainly ideological reasons); the prevailing part of a huge layer of various sources of the occupation period were written in Romanian, which also made them not very popular because of the lack of knowledge of the language of the neighbour in the Danube border area; the time required to familiarize Ukrainian scientists with the results of research on this issue passed, etc. Our creative tandem was among the first to study the history of the occupation policy of Romania in the interfluve of the Southern Bug and the Dniester, the territory that went down in history as the Transnistria Governorate, i.e., the land beyond the Dniester. A small essay was first published in the Encyclopedia of History of Ukraine, as well as a series of works on related topics, including education and religious life in Transnistria ${ }^{7}$. However, only the second decade of the 21 st century became somewhat fruitful. The issue of the administrative structure and governing bodies on the territory of southwestern Ukraine was studied mainly

1 Ancel Jan, Contribuții la istoria României. Problema evreiască. Vol. II, 1933-1944, Bucureşti: Editura Hasefer; Yad Vashem, 2003.

2 Golopentia Anton, Românii la Est de Bug. Vol. 2. București: Editura Enciclopedică, 2006, pp. 25-26.

3 Moraru A., Istoria românilor. Basarabia şi Transnistria. 1812-1993, Chişinău: Epigraf, 1995.

4 Petrencu Anatol, Romania şi Basarabia in anni celui de-al doilea razboi mondial. Chişinău: Epigraf, 1999.

5 Solovei Rodica, Activitatea Guvernamintului Transnistriei on domeniul social-economic şi cultural: 19 auq. 1941 - 29 ian. 1944, laşi, 2004.

6 Verenca 0., Administrația civilă română în Transnistria, Chişinău: Universitas, 1993; Ibid. Administrația civilă română în Transnistria, 1941-1944, Bucureşti: Vremia, 2000.

7 Mykhailutsa Mikola \& Nikulcha Igor, Transnistriia [Elektronnyi resurs]. Rezhym dostupu: http: //www.history.org. ua/?termin=Transnistriia; Mykhailutsa Mikola \& Nikulcha Igor, Bohoslovska osvita v “Transnistrii" za rumunskoho volodariuvannia (1941 -1944). Literatura ta kultura Polissia. Vyp. 27. Nizhyn: Nizhynskyi derzhavnyi pedahohichnyi universytet imeni M. Hoholia, 2004, s. 230-233; Mykhailutsa Mikola, Relihiina polityka rumunskoi okupatsiinoi vlady v Pivdennii Bessarabii i Transnistrii (kinets 1930-1944 rr.). Odesa: "Optimum”, 2006, 237 s.; Mykhailutsa Mikola, Pravoslavna tserkva na Pivdni Ukrainy v roky Druhoi svitovoi viiny (1939-1945). Odesa: "VMV", 2008, $392 \mathrm{~s}$. 
in the context of the general policy of the dictator I. Antonescu in the dissertations written by V.Shchetnikov ${ }^{8}$, N. Terefera ${ }^{9}$, O.Lysenko and V.Nesterenko ${ }^{10}, 0$. Novoselov $^{11}$, and in the articles by I.Tarnavsky ${ }^{12}$, Yu.Levchenko ${ }^{13}$. However, all these works suffer from a lack of a solid source basis since the Romanian archives were completely ignored. Our task is to present the reader with the best practices based on primary documents of Romanian origin from a wide range of archival institutions of Romania, Ukraine and Moldova, which significantly enhances the scientific product compared to the existing studies.

\section{General Characteristics of the Situation}

The zone of delimitation of territorial interests between the allies of Romania and Germany, the so-called Transnistria, included the territory between the Dniester and the Southern Bug with an area of $39,733 \mathrm{~km}^{2}{ }^{14}$ occupied by the Romanian troops. In our opinion, the determination of the total population in this region and its ethnic composition until the autumn of 1941, i.e., until the establishment of the actual occupation administration, remained an unresolved problem for many researchers. The main reason for this, in our opinion, is the internal policy of the Stalinist leadership of the USSR in the 1930s, based on a totalitarian regime, which undoubtedly had negative consequences in the demographic sense. "Terror by famine in Ukraine in 1932-1933"15, (named so by S. Kulchitsky), already recognized by many countries of the world as the genocide of the Ukrainian people, forced collectivization and mass deportation of peasant families to Siberia ${ }^{16}$, political repressions ${ }^{17}$, etc., led to a sharp reduction in the population of Ukraine as a whole, and the population of the Bug-Dniester region in particular. Certainly, this could not but determine the ethno-demographic situation on this territory directly during the war years, taking into account that the ethnic composition

8 Shetnykov Vasil, Do pytannia pro vtraty sered tsyvilnoho naselennia na pivdni Ukrainy pid chas nimetskorumunskoi okupatsii 1941-1944 rr. (problema dzherel). Storinky voiennoi istorii Ukrainy: zbirnik naukovih statei. NAN Ukrainy, Institut istorii Ukrainy. Kyiv, 2005. Vyp. 9. Chast. 2, s. 351-358.

9 Terefera Natallya, Okupatsiinyi rezhym na terytorii "Transnistrii" ("Zadnistrovia") v roky fashystskoi okupatsii kraiu (1941-1944 rr.). Storinky voiennoi istorii Ukrainy: zbirnik naukovih statei. NAN Ukrainy, Institut istorii Ukrainy. Kyiv, 2006. Vyp. 10. Chast. 1, s. 476-483.

10 Lysenko Oleksandr \& Nesterenko Vadim, Okupatsiinyi rezhym na Ukraini u 1941-1943 rr.: administratyvnyi aspect. Arkhivy okupatsii. 1941-1944. Kyiv: Vydavnichiy dim “Kyievo-Mohylianska akademiia”, 2006, s. 762-769.

11 Novosolov Oleksandr, Polityka Rumunii shchodo ukrainskykh zemel u period dyktatury I. Antonesku (1940-1944 rr.): avtoreferat dysertatsiyi. Chernivtsi, 2008.

12 Tarnavskyi Igor, Administratyvnyi podil ta orhany upravlinnia na terytorii pivdenno-zakhidnoi Ukrainy za chasiv rumunskoi okupatsii. Istorychni i politychni doslidzhennia. Kyiv, 2010. № 3-4. s. 210-216.

13 Levchenko Yuriy, Upravlinskyi aparat rumunskykh administratyvno-terytorialnykh odynyts Ukrainy pid chas okupatsii 1941-1944 rr. Naukovyi visnyk Skhidno-yevropeiskoho natsionalnoho universytetu imeni Lesi Ukrainky. Seriia: istorychni nauky. Lutsk, 2013, Vyp. 21(269), s.70-75.

14 Arhiva Nationala a Respublicii Moldova (ANRM), fund (f.) 706, inventori (inv.) 1, archive unit (a.u.) 482, sheet (sh.) 40.

15 Kulchytskyi Stanislav, Holodomor 1932-1933 rr. v Ukraini yak henotsyd, history.org.ua/JournALL/pro/14/14.pdf.

16 Conquest Robert, The Harvest of a sorrow: Soviet collectivization and the Terror-Famine. London, 1986.

17 Kostiuk Hryhory, Stalinist Rule in Ucraine: A Study of Mass Terror (1929-1939). Munich, 1960. 
of the population was very diverse, as Ukrainians, Russians, Moldavians (Romanians), Jews, Germans, Poles, Greeks, Bulgarians and other nations lived there. In addition, with the outbreak of the German-Soviet war in June 1941, part of the population was evacuated to the east of the USSR due to hostilities in the Dniester and the Southern Bug interfluve. For example, by October 16, 1941, about 200,000 inhabitants ${ }^{18}$ had left Odessa. As a result, the Romanian occupation administration had to deal with the statistical task. As early as November-December 1941, the administration had organized a general census of the population of Transnistria. To conduct the census, Inventory Commissions were established in each locality and district centres by Order No. 25 of the governor of Transnistria. The technical implementation of the census was provided by 143 employees of the Central Institute of Statistics of Romania, who were sent to the occupied lands ${ }^{19}$. According to the results, the population of Transnistria was 2,326,226 people ${ }^{20}$.

\section{Administrative Structure of Transnistria}

The Romanian administration, headed by Governor G.Alexianu, defined the situation in the region as fully destroyed by the war, when there was not a single existing administrative body or establishment. Indeed, there was a real administrative, legal, and economic vacuum since the Soviet authorities, while retreating, destroyed and evacuated important objects of the economy, industry, etc., which led to administrative "paralysis" in this territory.

The poor population, deprived of faith and trust in the former government which had abandoned it and was hastily retreating, was very demoralized by the war. This situation required the restoration of internal order, control and prestige of the occupation power, administrative and economic reorganization, and stabilization of the moral and social condition of the population. In order to assist Governor G. Alexianu, the German Baron von Malhius ${ }^{21}$ was involved as a technical adviser, who initiated the application of the "Rosenberg norms", used in the territories of the USSR occupied by the Nazis ${ }^{22}$, in Transnistria. They provided for the complete replacement of the Soviet system and the introduction of a new administrative organization of the territory. However, $\mathrm{G}$. Alexianu decided that it would be more expedient not to introduce the system proposed by the Germans, but to organize life in Transnistria, making minor adjustments, attracting as many local specialists as possible to local authorities. In

18 Odessa v Velikoj Otechestvennoj Vojne Sovetskogo Sojuza. Sbornik dokumentov i materialov. Tom 2. Odessa: Odesskoe oblastnoe izdatel'stvo, 1949-1951, s. 4.

19 Golopentia Anton, Românii la Est de Bug. Vol. 2. București: Editura Enciclopedică, 2006. p. 25-26.

20 Guvernamantul Transnistriei, Transnistria. Un an de la caderea Odessei. 16 octombrie 1942-16 octombrie 1942. Bucuresti: “Luceafarul” S.A.R., 1943, p. 9.

21 Procesul mareşalului Antonescu. Documente, Vol. 3. ed. Marcel Dumitru Ciucă. Bucureşti: Editura Saeculum,1998. p. 453.

22 Dallin Al., German Rule in Rusia. London, 1957; Schulte Th.J., The German Army and Nazi Policy in Occupied Russia. Oxford, 1989; Mulligan T.P., The Politics of Illusion and Empire. German Occupation Policy in the Soviet Union. 1942-1943. New York, 1988. 
this context, it was supposed to create an administration that would work in the direction of "maximizing the use of the resources of the occupied territory in accordance with the laws of war"23.

At that time, G. Alexianu proudly informed Marshal I. Antonescu that he had conceived and structured the occupation administration according to the "Führer principle" (German: Fuhrerprinzip), which meant "One person, one direction, one responsibility". According to G. Alexianu, the power scheme was as follows:

\begin{abstract}
"The will of this one person is transmitted from the centre to the periphery, and this one will orders and fulfils. In Transnistria, the will of the Supreme Commander-in-chief Marshal Ion Antonescu, is transmitted through the civil governor to the most remote peripheral organs and is thereby fulfilled"24.
\end{abstract}

On September 12, 1941, Governor G. Alexianu signed Order No. 8 on the administrative structure of the occupied territories. Transnistria was divided into communes and towns, districts and counties ${ }^{25}$. All settlements in Transnistria formed communes (a rural community - village), which were governed by the mayor with the assistance of the village council consisting of 3 people ${ }^{26}$. The mayor and council members were elected by the assembly of the village from among local residents and approved by the head of the district - a pretor. The administration of the commune was called the mayor's office. Within Transnistria, there were 1,363 rural communities, which included 2,568 villages and 74 hamlets $^{27}$.

The settlements that had a city administrative organization retained the status of a city. The city was governed by a mayor and one or two deputies, depending on the number of residents in the city. The mayor and his deputies were appointed by the prefect (the county head $)^{28}$. There were 15 cities on the territory between the Dniester and the Southern Bug, most of which had a county status: Ochakov (4,000 people), Mogilev (25,000 people), Ovidiopol (5,000 people), Kamenka (7,000 people), Rybnitsa (10,000 people), Dubossary (30,000 people), Grigoriopol (12,000 people), Bar (20,000 people), Tulchin (14,000 people), Balta (23,000 people),

23 Gherasim D., Regulile ocupației de război. (Cu privirea specială la administrația germană din teritoriile ocupate în războiul actual). Extras din revista «Pandectele Române», nr. 2. București, 1944. p. 16.

24 State Archives of Odesa Region (SAOR), f. P-2242, inv. 1c, a.u. 677, sh. 18-196.

25 SAOR, f. P-2359, inv. 1, a.u. 1, sh. 1.

26 Arhiva Ministerului Apărării Naționale a României (AMApN), fund (f.) Armata a 4-a, rola (r.) 205, dosar (d.) 1079 , file (f.) 14; United States Holocaust Memorial Museum (USMM), RG 25003M, f. Armata a 4-a, r. 12, d. 1079; ANRM, f. 706, inv.1, a.u. 41, sh. 321.

27 ANRM, f. 706, inv. 1, a.u. 482, sh. 140.

28 AMApN, f. Armata a 4-a, r. 205, d. 1079, f. 14; USMM, RG 25003M, f. Armata a 4-a, r. 12, d. 1079; ANRM, f. 706, inv. 1, a.u. 41 , sh. 321. 
Berezovka (6,000 people) and Yampol (7,000 people $)^{29}$. In the largest cities, municipalities were organized, they were in the first (temporary) capital of Transnistria - Tiraspol (40,000 people) and in Odessa $(272,378 \text { people })^{30}$, which became the capital of Transnistria on October $17,1941^{31}$. In these cities, the mayors of the municipalities were appointed directly by the governor of Transnistria.

A district was the administrative and territorial unit, which the communes were subordinate to, and, accordingly, which included a certain number of settlements. The average area of the district ranged from $50-80 \mathrm{~km}^{2}$, and the number of inhabitants ranged from 30,000 to 50,000 people. In fact, the district was the most important administrative and economic link, and it was upon this that the management system of the Transnistria Governorate was based. The district had the status of a legal entity and its own budget ${ }^{32}$. The Romanian occupation authorities kept the areas within the borders that existed during the Soviet power since the distribution of land, the organization of institutions, enterprises and public places had already been debugged, and any changes would have caused a disruption in normal life ${ }^{33}$. The entire territory of the governorate was divided into 64 districts ${ }^{34}$. Each district was under the authority of a pretor (the head of the district administration), appointed by the governor of Transnistria. At first, the management of the districts was carried out by the former local leaders, however, 64 pretors from Romania were soon sent from among the graduates of law faculties, who were selected as a result of a competition held by the Ministry of the Interior ${ }^{35}$. Obviously, in order to maintain continuity in management, the former leadership of the districts was left in the service as assistant pretors. All district officials were subordinate to the pretor, regardless of whether they were administrative employees or specialists in various fields ${ }^{36}$. The administration of the district was called the pretor's office, which was entrusted with the following functions (within the district): - administrative supervision of rural and urban communities; - supervision and maintenance of public order in the district with the help of the county police and the gendarmerie; - monitoring the administrative activities of the district specialists - a doctor, a veterinarian, an agronomist, an engineer, a head of the department of education, etc., applying disciplinary sanctions to them, if necessary ${ }^{37}$. In accordance with Order

29 Popp Nicolae, Transnistria. Încercare de monografie regională. în Biblioteca revistei “Moldova Nouă”, nr. 2, 1943, pp. 184-195.

30 ANRM, f. 706, inv.1, a.u. 529, sh. 20.

31 Arhivele Nationale Bucuresti (ANB), f. PCM, a.u. 579/1941, sh. 5.

32 Verenca O., Administrația civilă română in Transnistria 1941-1944. Ediția a II-a îngrijită dr Șerban Alexianu. București: Editura Vremea, 2000, p. 93.

33 Negulescu Paul, Istoricul județelor în România. în “Revista de drept public”, nr.1-2, 1942, s. 105.

34 SAOR, f. P-2361, inv. 1, a.u. 47, sh.sh.1-30.

35 ANRM, f.706, inv. 1, a.u. 529, sh. 4.

36 Guvernamantul Transnistriei, Transnistria. Un an de la caderea Odessei. 16 octombrie 1942 - 16 octombrie 1942. Bucuresti: "Luceafarul” S.A.R., 1943, p. 11.

37 AMApN, f. Armata a 4-a, r. 205, d. 1079, f. 14; USMM, RG 25003M, f. Armata a 4-a, r. 12, d. 1079; ANB, f. PCM, a.u. 477/1942, sh. 11. 
No. 8, the departments of agriculture, engineering, economy, finance, commerce, education, sanitary, roads, postal service and telephones, veterinary, transportation, and construction were created in each district. Accordingly, the department of administration was created for management and control ${ }^{38}$.

Almost the entire staff of district officials and specialists was recruited from among the local residents who went to work according to Order No. 2, issued by the governor of Transnistria on August $28,1941^{39}$. The incomplete number of people was staffed by the officials from Romania. In each district, the number of administrative employees ranged from 24 to 45 people.

The counties, which included 3-8 districts, were created to guide the activities of the districts, control the pretors, and coordinate their work. The counties did not have the status of a legal entity and did not have their own budget ${ }^{40}$. At the end of August 1941, the administrative bodies were formed in the western territory of Transnistria in the following districts: Tiraspol, Ananyev, Balta, Jugastru (Yampil) and Mogilev-Podolsky. As Wehrmacht troops and the Romanian army advanced eastward in October 1941, an administration was established throughout the occupied lands. Thus, 13 counties were created: Ananyev, Balta, Berezovka, Dubossary, Golta, Jugastru, Mogilev, Ochakov, Odessa, Ovidiopol, Rybnitsa, Tiraspol, Tulchin. The administration of each county was called a "prefecture" and was headed by a prefect (the head of a county), who had the functions of a general administrative inspector. The prefects were appointed by the governors from among the militaries, who mainly held the rank of colonel. The following prefects headed the districts respectively: K. Belintinyanu, V. Nica, L. Pop, A. Batcu, M. Isopescu, Sh. Georgiade, K. Login, I. Constantinescu, M. Valcescu, N. Canar, K. Popescu-Korbu, P. Georgescu and C. Nesturas ${ }^{41}$. Each prefect had two deputies - sub-prefects who spoke local languages (Ukrainian, Russian, Bulgarian, Moldavian/Romanian). Usually, one of them was a representative of the local population, and the other was from Bessarabia ${ }^{42}$. The incomplete prefectural staff, in most cases, was filled with the local residents, former Soviet officials. The number of employees in the prefectures ranged from 10-12 people ${ }^{43}$. The police and gendarmerie were subordinate to the prefect, which gave him exclusive authority in the county. Under the rules established by the governor, the prefect had the right to appoint or remove any official in the county, including the mayors and their assistants, to approve village councils and so on ${ }^{44}$.

38 ANRM, f.706, inv. 1, a.u. 41, sh.sh. 32-35.

39 ANRM, f.706, inv. 1, a.u. 37, sh.sh. 39-51.

40 Negulescu Paul, Istoricul județelor în România. în "Revista de drept public", nr.1-2, 1942, p. 105.

41 ANRM, f. 706, inv. 1, a.u. 1054-1, sh. 12; SAOR, f. P-2242, inv. 1, a.u. 6926, sh.sh. 91-92; SAOR, f. P-2242, inv. 4c, a.u. 50, sh.sh. 81-82.

42 ANB, f. PCM, a.u. 597/1941, sh. 3.

43 Guvernamantul Transnistriei, Transnistria. Un an de la caderea Odessei. 16 octombrie 1942 - 16 octombrie 1942. Bucuresti: "Luceafarul” S.A.R., 1943, p. 11.

44 Verenca 0., Administrația civilă română in Transnistria 1941-1944. Ediția a Il-a îngrijită dr Șerban Alexianu. București: Editura Vremea, 2000, p. 94. 
If the district prefecture was the main economic administrative unit, the county prefecture carried out political and coordinating functions. To ensure effective management, the entire Romanian occupation administration in Transnistria was directly subordinated to the Commander-in-chief of the Romanian Army Marshal I. Antonescu, and the civilian governor of Transnistria G. Alexianu ${ }^{45}$, who was appointed by I. Antonescu. It should be noted that G. Alexianu held a professorship and was considered an authoritative specialist in the field of constitutional and administrative law in legal circles ${ }^{46}$. At the same time, he had extensive managerial experience as a royal resident of the districts of Suceava and Bucegi (Bucegi had about the same area $\left(40,879 \mathrm{~km}^{2}\right)$ as Transnistria, but a significantly larger population $(3,806,744$ people $))^{47}$. In our opinion, these qualities of Prof. G. Alexianu played a decisive role in his appointment to the position of the civilian governor of Transnistria.

The governor, respectively, was the chief administrator and authorized officer of the Commander-in-chief of the army in the occupied territory and had a number of broad powers, among which we would like to highlight the following ones: to implement the policy pursued by the Commander-in-chief of the army in Transnistria; to exercise control over all bodies subordinate to him and their documentation as the highest head of the entire administrative staff of the governorship; to develop decisions, instructions, and issue orders applicable throughout the territory of Transnistria as a representative of the ultimate authority in the governorate; as the chief of police, he was responsible for public order, he could give orders to the police and the Siguranza and, if necessary, even demand the use of the army ${ }^{48}$.

Thus, the power vertical in Transnistria was presented as follows: The Supreme High Command (Supreme Commander) - the central apparatus of the Transnistria Governorate (governor) - county prefectures (prefect) - district pretors' offices (pretors) - rural communities (mayors), and cities (mayors).

The governor exercised his leadership through the departments created by Decree No. 1 of August 19 1941, together with the relevant services. Initially, the Department of Administration and Communications, the Department of Agriculture and Economy, the Department of Education and Propaganda, the Department of Health, and the Department of Finance functioned ${ }^{49}$. As the activities of the Romanian occupation administration in Transnistria

45 ANB, f. PCM, a.u. 597/1941, sh. 3.

46 George Alexianu was one of the founders of the Romanian Institute of Administrative Sciences in Bucharest. He was also a member of the Institute of Philosophy of Law, a member of the International Institute of Administrative Sciences in Brussels. Professor George Alexianu wrote a number of scientific works and monographs: Alexianu Gh. Curs de drept constituțional. Vol. I-III. Bucureşti, 1930-1937; Alexianu Gh. Repertoriul general alfabetic al tuturor codurilor, legilor, decretelor-legi. 1 ianuarie 1860 - 1 ianuarie 1940. Vol. I-II, Bucureşti, 1940; Negulescu P., Boilă R., Alexianu Gh. Codul administrativ adnotat. Bucureşti, 1930; Negulescu P., Alexianu Gh. Tratatul de drept public. Vol. 1-2. Bucureşti, 1942-1943.

47 Verenca 0., Administrația civilă română în Transnistria. Chişinău: Universitas, 1993, p. 222.

48 Nistor I., Istoria românilor din Transnistria. Bucuresti: Editura Eminescu, 1995, p. 89.

49 ANB, f. PCM, a.u. 597/1941, sh. 2. 
changed, the departments, which were created by Decree No. 1/1941 and covered several directions, were divided and the new ones arose. Thus, their number grew to $22^{50}$. In addition to the aforementioned departments, the Bureau of Studies, the Bureau of Statistics, the corps of general administrative inspectors, the police and the gendarmerie were under the direct supervision of the governor ${ }^{51}$.

At the same time, the administrative organization of the southern and south-eastern territory of Transnistria and, in particular, the city of Odessa became possible after the cessation of hostilities and the seizure of Odessa on October 16, 1941. Therefore, until the end of October 1941, Ovidiopol, Ochakov and Odessa counties were partially controlled by the commanders of labour battalions serving as prefects of these counties.

It is also important to focus on administrative tasks since along with the civil administration in Odessa, there was a military command. Its mission was to ensure order and security of the city, as well as land, sea and air defence of Odessa and its suburbs. In addition, the military administration was supposed to save communal property (plants and factories, technical structures, warehouses, state institutions, cultural and educational institutions, etc.) from destruction and devastation ${ }^{52}$. Immediately after the entry of the troops into the city, the military command had to take all necessary measures to establish and organize the work of the occupation civil authorities. To accomplish these tasks, the Romanian military were carrying out the planned actions in two stages. In the first stage, after having captured the city, they immediately seized the property and city objects that had not been evacuated, taking them under control. In the second stage of the transfer of power from the military to the civilian authorities, it was envisaged to carry out accounting of the city property, commissioning various industrial enterprises and normalizing city life $\mathrm{e}^{53}$.

Following October 16, 1941, to ensure order and quick restoration of the resilience of the city, all civil authorities were subordinate to the military command of Odessa ${ }^{54}$. As the administrative bodies began to function using their own civilian forces and personnel, the guardianship of the military command was limited only to their direct functions. For example, with the assumption of duties of the civil governor of Transnistria G. Alexianu, the military commandant, having the city police prefecture in his subordination, solely carried out the function of ensuring order and security, protecting enterprises and institutions, and the organizational and administrative function passed into the hands of the civilian authorities $^{55}$. The police in the city of Odessa remained under the control of the military until the Transnistrian Gendarmerie Inspectorate, which was subordinate to the governor

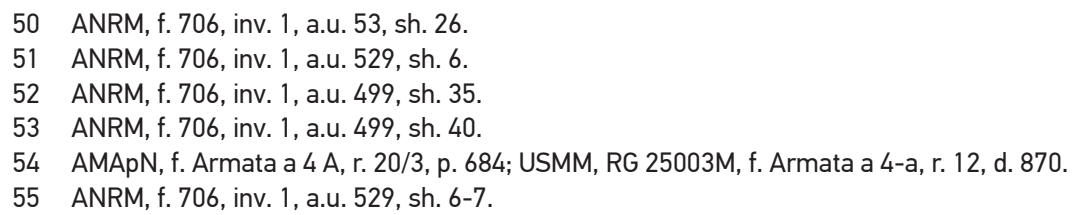


and which did not subjugate the prefecture of the police of Odessa, citing the achievement of unity of action and information ${ }^{56}$.

On October 18, 1941, by Decree No. 1559, G. Pântea ${ }^{57}$, a native of Bessarabia, was appointed the mayor of Odessa. V. Ciorescu, E. Sinikliu, K. Vidraška were deputy mayors (vice mayors), and A. Costinescu was the General Secretary. Later, two more deputies from among the local residents - V. Kundert and M. Zaevloshin - were appointed ${ }^{58}$.

Before the war, Odessa was the largest seaport of the Soviet Union on the Black Sea as well as being a large industrial, commercial, and cultural centre with a population of 500-600 thousand people 59 . The defence of Odessa from capture by the Romanian army lasted 73 days, until October 16, 1941. During this period, the Soviet authorities managed to evacuate 23,000 tons of weapons, ammunition and military equipment, 188,000 tons of industrial equipment (factories, plants) and approximately 200,000 civilians and the military ${ }^{60}$. As throughout Transnistria, the situation in Odessa was also catastrophic - with a devastated and ruined city, the economic life was destroyed as well as the entire city infrastructure. To restore the city's life and to repair and put into operation industrial enterprises (primarily the food industry), it was necessary to reorganize and equip all public utilities and municipal services. Five departments were created in the mayor's office, which covered various areas of social and economic activities: economic sphere, municipal services, culture, and communal property, registry office and technical department. Each of these departments was managed by one of the mayor's assistants ${ }^{61}$.

Between the beginning of November 1941 and February 1942, a population census was conducted in Odessa by the municipal authorities using the employees of the legal bureaus of nine police stations in the city ${ }^{62}$. The total population of the city was 272,378 people $e^{63}$. It should be taken into consideration that the Jewish inhabitants were not included in this number; some of them were killed because of mass repressions of the occupation authorities in late October - early November 1941. Obviously, the Jews who were deported in several waves from Odessa in November by the Nazis, were not included in the indicated number in November 1941 according to Order No. 35 of 02.01 .1942 by the governor of Transnistria G. Alexianu, starting January $10,1942^{64}$.

56 ANRM, f. 706, inv. 1, a.u. 529, sh. 6.

57 Pântea German (1894-1967), a Bessarabian, received his education in Odessa and Kiev. During World War I he served in the army of the Russian Empire; he was a member of the Parliament - "Sfatul Tsarii" in Bessarabia. Former mayor of Kishinev. He was fluent in Russian.

58 ANRM, f. 706, inv. 1, a.u. 518-1, sh. 242.

59 Dallin Al., Odessa, 1941-1944: A Case study of Soviet Territory under foreign rule. California, Santa Monica: The Rand Corporation, 1957, p. 56.

60 Odessa v Velikoj Otechestvennoj Vojne Sovetskogo Sojuza. Sbornik dokumentov i materialov. Tom 2. Odessa: Odesskoe oblastnoe izdatel'stvo, 1949-1951, p. 4.

61 SAOR, f. P-2272, inv. 1, a.u. 12, sh.sh. 5-6.

62 ANRM, f. 706, inv. 1, a.u. 1219-2, sh. 287.

63 ANRM, f. 706, inv. 1, a.u. 1219-2, sh. 291.

64 ANRM, f. 706, inv. 1, a.u. 37, sh. 66. 
To establish the functioning of the administration and ensure livelihoods in the occupied territory, the Romanian authorities felt the need for qualified personnel in various areas of economy, transport, and management. The personnel, hired by the civilian administration of Transnistria, represented mainly two categories:

1. Officials, employees, and specialists seconded from various institutions of Romania or directly employed by the governorate in Romania. They were mainly distributed in the central apparatus of the governorate and in local authorities: in the prefectures of the districts, municipalities, and cities, as well as in various central institutions and enterprises of the governorate.

2. Officials, employees and specialists hired from the local population, who mainly worked in non-senior positions in the administration, enterprises, prefectures, districts, agricultural communes, factories and other industries. In addition to these categories, immigrants from Bessarabia were part of the staff, and according to A. Dallin, they were fluent in Russian and Ukrainian and before the annexation of the USSR (until the summer of 1940) were considered to be Romanian citizens ${ }^{65}$.

On August 28, 1941, the governor of Transnistria G. Alexianu, issued Order No. 2, which obligated:

"All persons who held any positions or were in charge of property on collective farms or state farms shall come to the local authorities to obtain permission for further activities"66.

In fact, by this order, the Romanian administration gave the "green light" to attract local people to cooperate and to recruit central and local authorities for administrative and economic structures of the Transnistria Governorate. Work experience, professionalism and loyalty to the new government played a decisive role in hiring. Naturally, persons who performed the leading functions in the All-Union Communist Party (bolsheviks) (VKP(b) and in the repressive organs of the Soviet power (the State Political Administration (GPU), the People's Commissariat for Internal Affairs (NKVD) under the Soviet regime were deprived of the right to occupy leading administrative and economic positions and functions. Nationality did not play a significant role in employment. On the contrary, if, for example, the majority of the inhabitants of the settlement were Ukrainians, Ukrainian employees were attracted. Persons of Moldavian and German nationalities had certain preferences in employment. But eventually, the professionalism of the employee played a defining role. Jews, for well-known reasons, dictated by the anti-Semitism of the ruling regime of I. Antonescu, were excluded from all spheres of the life of the governorate.

65 Dallin Al., Odessa, 1941-1944: A Case study of Soviet Territory under foreign rule. California, Santa Monica: The Rand Corporation, 1957, p. 81.

66 USMM, RG 25003M, f. Armata a 4-a, r. 12, d. 1079. 
For Romanian officials and specialists sent from Romania to work in Transnistria, according to Art. 4 of Decree No. 1 of August 19, 1941, "double salary in lei and a supporting allowance in R.K.K.S. ${ }^{67}$ up to double salary in lei ${ }^{68 "}$ were paid. The Decree-law No. 3247, signed by vice-chairman of the Council of Ministers of Romania M. Antonescu on November 22, 1941, specified:

\begin{abstract}
"All the functionaries of the civil governorate, under Military occupation command in Transnistria, are mobilized at the place of their work, at the time of the publication of this Decree-law, under the conditions provided for in Article 11 of Law No. 105 (1933) on the organization of the nation and territory during the war, as amended by the Decree-law published in the Official Gazette No. 189 (1939) and supplemented by the Decree-law No. 642 (1941) published in the Official Gazette No. 61 in 1941"69.
\end{abstract}

As a result, 8,445 officials and specialists were sent from Romania, of which 4,471 were sent by various authorities from Romania, and 3,674 were hired directly by the governorate ${ }^{70}$. The immigrants from Bessarabia and Bukovina accounted for a large part among this category of officials. In the governorate, the total number of functionaries (administrative employees and officials, specialists), who worked both in central administrative bodies, institutions, institutes and enterprises, and in local government and economy structures, amounted to 37,856 people. Of these, respectively, 11,423 people worked in the central organs of the governorate, and 26,433 people worked in local governments. Of the employees who came from Romania, as mentioned above, only 2,363 were administrative officials, and the majority (6,082 people), were hired specialists. More than half (3,473 people) of this number were railway workers, and transport and technical specialists ${ }^{71}$. In Transnistria, 9,135 administrative officials and 20,276 specialists, who were recruited from the local population, worked.

In total, 3,216 Romanian and 8,207 local employees worked in the central structures of the Transnistria Governorate, and 21,411 officials and employees from Transnistria and 5,229 officials and specialists from Romania worked in county, district and local authorities ${ }^{72}$.

It should be noted that in most cases the senior administrative positions of the first level in the vertical of power (prefects, pretors, heads of power structures) and horizontally in power (heads of departments of the governorate) were occupied only by Romanian citizens. The locals who worked in the Transnistrian administration generally performed technical functions.

67 R.K.K.S. (Reichskreditkassenschen) - the monetary unit that operated in Transnistria and was issued by Germany specifically for the occupied territory (1 R.K.K.S. $=60$ lei).

68 ANB, f. PCM, d. 597/1941, sh. 2.

69 Verenca 0., Administrația civilă română în Transnistria. Chişinău: Universitas, 1993, pp. 30-31.

70 ANRM, f. 706, inv. 1, a.u. 518-1, sh. 8.

71 ANRM, f. 706, inv. 1, а.u. 518-1, sh. 7-8; SAOR, f. P-3366, Транснистрия, 1941-1943, sh. 30.

72 ANRM, f. 706, inv. 1, a.u. 518-1, sh. 9. 


\section{Diagram I.}

\section{The ratio of the number of officials and specialists in Transnistria during the Romanian occupation between 1941 and 1944 (\%)}

In the same context, analysing the statistical indicators for administrative officials and for employees and specialists separately, it is possible to reconstruct the following picture: among administrative officials, the proportion of the representatives of the local population was $79 \%$, and Romanians was $21 \%$. Among the employees and specialists (representatives of different professions) who worked in budgetary institutions and at the enterprises of the Transnistria Governorate, these indicators are as follows: $77 \%$ and $23 \%$, respectively.

Consideration of the representation of local officials, employees, specialists on the one hand, and Romanian officials, employees, specialists in the central and local administrations of the Transnistria Governorate, on the other hand, gives us slightly different results: $71.84 \%$ of the local residents worked in the central administration, and Romanians accounted for $28.2 \%$. In the institutes and the bodies of local administrations, these indicators were as follows: $80.2 \%$ and $19.8 \%$, respectively. As you can see, the difference of about $8 \%$ does not significantly change anything, although a tendency in favour of the occupiers is observed. Obviously, this is due to the distrust of the occupation authorities towards the local population, at the lower administrative level, and the desire to concentrate power and managerial tools in the hands of the central apparatus of the occupation administration. In fact, it made the system of subordination and control over the economy in the occupied territory, as well as the exploitation of labour and population resources, more efficient.

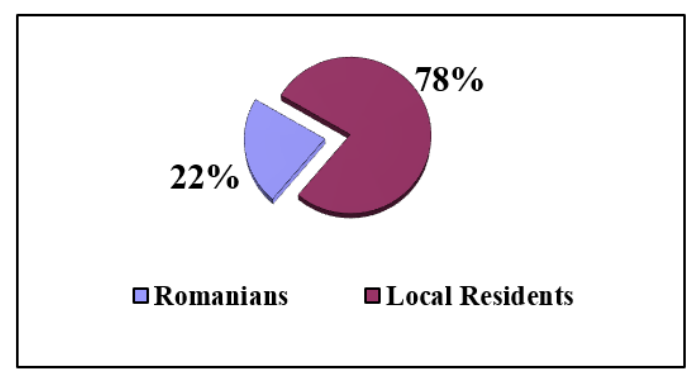

Thus, on the basis of a set of documentary materials and statistical data, it is possible to assert that the Romanian administration in Transnistria relied mainly on the involvement of local staff. The ratio of the representatives of the local population and Romanian citizens working in the system of the Romanian occupation administration was approximately 1:4. The high level of cooperation of the local population with the occupying Romanian authorities is a characteristic and a distinctive feature of the Romanian occupation regime in Transnistria, which, in comparison with the Nazi regime of the German Reich, was significantly more liberal 
in some ways (entrepreneurship, trade, religious and cultural life). It is very difficult to determine the ethnic and social composition of the local and involved collaborators, which may be the subject of further research. One thing is sure: persons of Jewish and Roma nationalities, who were subjected to destruction and deportation, were the exception. Their representatives were completely excluded from the public, economic, social and cultural activities, and everyday life of Transnistria. For the rest, the Romanian authorities did not carry out pronounced ethnic discrimination when hiring the local population for working in the state and economic structures of the Transnistria Governorate, although preferences extended to ethnically close Moldavians and allies in the anti-communist block of Germans.

\section{The Final Months of the Occupation}

On January 29, 1944, by order of Marshal Antonescu, the civil governor of Transnistria G. Alexianu, was replaced by General G. Potopianu. By this decision, power was transferred from the civilian administration of Transnistria to the "Romanian military administration in the territory between the Dniester and the Bug"73. General G. Potopianu, even at the beginning of the Romanian civil administration in Transnistria, acted as a secretary-general of the governor of Transnistria, i.e., he was Alexianu's Deputy. Potopianu assumed the position of the head of the Romanian military administration on February 2, 1944. The simplification of the administrative apparatus was one of the first measures taken by him. As can be seen from the above, it was a very complex and overly centralized body that subordinated even small administrative institutions to the governor. General G. Potopyanu reduced the number of the departments, defining their tasks in more detail. At the same time, the administrative and territorial system was simplified, the number of prefects was reduced by half (from 13 to 6), which corresponded to the so-called military sectors, grouped into two regions: northern and southern ${ }^{74}$.

On March 13, 1944, the Romanian military administration began transferring the province to German troops as a result of the Soviet offensive ${ }^{75}$, and five days later the territory between the Dniester and the Southern Bug, as A. Hillgruber emphasizes, became a zone of military operations controlled by the Germans ${ }^{76}$. According to I. Nistor, the Romanian administration of Transnistria was finally eliminated on April 1, 1944 ${ }^{77}$. The offensive advance of the Red

73 Verenca O., Administrația civilă română in Transnistria 1941-1944. Ediția a Il-a îngrijită dr Șerban Alexianu. București: Editura Vremea, 2000, pp. 200-201.

74 Kirițescu C., România în al doilea război mondial. Vol. 2. Text stabilit și îngrijit, adnotat și comentat; însoțit de un indice general de nume și de o bibliografie curentă de referință de Gh. Buzatu. Cu un cuvânt înainte de acad. Costin C. Kirițescu. București, 1996, p. 63.

75 USHMM, RG-25004M, Serviciul Roman de Informatii (SRI), r. 20, f. 40010, vol. 96, p. 50.

76 Hillgruber A. Hitler, Regele Carol şi Mareşalul Antonescu. Relațiile germano-române (1938-1944). Bucureşti: Editura Humanitas, 1994, p. 222.

77 Nistor Ion, Istoria românilor din Transnistria. Bucuresti: Editura Eminescu, 1995, p. 97. 
Army predetermined it. It was during this period when the troops of the 1st Ukrainian Front, commanded by General I. Konev, reached the north of Romania, and the front line was temporarily set at $120 \mathrm{kms}$ from the Romanian city of lași. Meanwhile, the troops of the 3rd Ukrainian Front, under the command of General R. Malinovsky, continued their offensive along the Black Sea coast and liberated Odessa on April 10, 1944 ${ }^{78}$. The liberation of this territory from German and Romanian troops became a fact.

Peer-review: Externally peer-reviewed.

Conflict of Interest: The author has no conflict of interest to declare.

Grant Support: The author declared that this study has received no financial support.

Hakem Değerlendirmesi: Dış bağımsız.

Çıkar Çatışması: Yazar çıkar çatışması bildirmemiştir.

Finansal Destek: Yazar bu çalışma için finansal destek almadığını beyan etmiştir.

\section{Bibliography}

\section{Archival Sources}

Arhiva Nationala a Respublicii Moldova (ANRM), fund (f.) 706, inventori (inv.) 1, archive unit (a.u.) 37, sheet (sh.) 39-51, 66.

ANRM), f. 706, inv. 1, a.u. 41.

ANRM), f. 706, inv. 1, a.u. 53.

ANRM), f. 706, inv. 1, a.u. 482.

ANRM), f. 706, inv. 1, a.u. 499.

ANRM), f. 706, inv. 1, a.u. 518-1.

ANRM), f. 706, inv. 1, a.u. 529.

ANRM), f. 706, inv. 1, a.u. 1054-1.

ANRM), f. 706, inv. 1, a.u. 1219-2.

State Archives of Odesa Region (SAOR), f. P-2242, inv. 1, a.u. 677.

SAOR, f. P-2242, inv. 1, a.u. 6926.

SAOR, f. P-2242, inv. 4c, a.u. 50.

SAOR, f. P-2272, inv. 1, a.u. 12.

SAOR, f. P-2359, inv. 1, a.u. 1.

SAOR, f. P-2361, inv. 1, a.u. 47.

SAOR, f. P-3366, inv. “Транснистрия”, 1941-1943.

Arhiva Ministerului Apărării Naționale a României (AMApN), fund (f.) Armata a 4-a, rola (r.) 205, dosar (d.) 1079, file (f.) 14.

AMApN, f. Armata a 4 A, r. 20/3, f. 684.

78 Werth Alexander, Un corespondent pe frontul de Est. Bucureşti: Editura Politică, 1970, p. 651. 
United States Holocaust Memorial Museum (USHMM), RG 25003M, fond (f.) Armata a 4-a, reel (r.) 12 , dosar (d.) 870.

USMM, RG 25003M, f. Armata a 4-a, r. 12, d. 1079.

USHMM, RG-25004M, Serviciul Roman de Informatii (SRI), r. 20, f. 40010, vol. 96, p. 50.

Arhivele Nationale Bucuresti ANB, f. PCM, d. 477/1942.

ANB, f. PCM, d. 579/1941.

\section{Books and Articles}

Ancel Jan, Contribuții la istoria României. Problema evreiască. Vol. II., 1933-1944. Bucureşti: Editura Hasefer; Yad Vashem, 2003, 421 p.

Conquest Robert, The Harvest of a sorrow: Soviet collectivization and the Terror-Famine. London, 1986.

Dallin Al., Odessa, 1941-1944: A Case study of Soviet Territory under foreign rule. California, Santa Monica: The Rand Corporation, 1957.

Dallin Al. German Rule in Rusia. London, 1957.

Gherasim D. Regulile ocupației de război. (Cu privirea specială la administrația germană din teritoriile ocupate în războiul actual ). Extras din revista «Pandectele Române», nr. 2. București, 1944.

Golopentia Anton. Românii la Est de Bug. Vol. 2. București: Editura Enciclopedică, 2006.

Guvernamantul Transnistriei, Transnistria. Un an de la caderea Odessei. 16 octombrie 1942-16 octombrie 1942. Bucuresti: "Luceafarul” S.A.R., 1943.

Hillgruber A., Hitler, Regele Carol şi Mareşalul Antonescu. Relațiile germano-române (1938-1944). Bucureşti: Editura Humanitas, 1994.

Kirițescu C.I., România în al doilea război mondial. Vol. 2. Text stabilit și îngrijit, adnotat și comentat; însoțit de un indice general de nume și de o bibliografie curentă de referință de Gh. Buzatu. Cu un cuvânt înainte de acad. Costin C. Kirițescu. București, 1996.

Kostiuk Hryhory, Stalinist Rule in Ukraine: A Study of Mass Terror (1929-1939). Munich, 1960.

Kulchytskyi Stanislav, Holodomor 1932-1933 rr. v Ukraini yak henotsyd, history.org.ua/JournALL/ pro/14/14.pdf.

Levchenko Yuriy, Upravlinskyi aparat rumunskykh administratyvno-terytorialnykh odynyts Ukrainy pid chas okupatsii 1941-1944 rr. Naukovyi visnyk Skhidno-yevropeiskoho natsionalnoho universytetu imeni Lesi Ukrainky. Seriia: istorychni nauky. Lutsk, 2013, Vyp. 21 (269), s. 70-75.

Lysenko Oleksandr \& Nesterenko Vadim, Okupatsiinyi rezhym na Ukraini u 1941-1943 rr.: administratyvnyi aspect. Arkhivy okupatsii. 1941-1944. Kyiv: Vydavnichiy dim “Kyievo-Mohylianska akademiia", 2006, s. 762-769.

Moraru A. Istoria românilor. Basarabia şi Transnistria. 1812-1993. Chişinău: Epigraf, 1995. 403 p.

Mulligan T.P. The Politics of Illusion and Empire. German Occupation Policy in the Soviet Union. 19421943. New York, 1988.

Mykhailutsa Mikola, Relihiina polityka rumunskoi okupatsiinoi vlady v Pivdennii Bessarabii i Transnistrii (kinets 1930-1944 rr.). Odesa: "Optimum", 2006, 237 s.

Mykhailutsa Mikola, Pravoslavna tserkva na Pivdni Ukrainy v roky Druhoi svitovoi viiny (1939-1945). Odesa: "VMV", 2008, $392 \mathrm{s.}$

Mykhailutsa Mikola \& Nikulcha Igor, Transnistriia [Elektronnyi resurs]. Rezhym dostupu: http: //www. history.org.ua/?termin=Transnistriia. 
Mykhailutsa Mikola \& Nikulcha Igor, Bohoslovska osvita v “Transnistrii" za rumunskoho volodariuvannia (1941-1944). Literatura ta kultura Polissia. Vyp. 27. Nizhyn: Nizhynskyi derzhavnyi pedahohichnyi universytet imeni M. Hoholia, 2004, s. 230-233.

Negulescu Paul, Istoricul județelor în România. în "Revista de drept public". nr.1-2, 1942.

Nistor I.S., Istoria românilor din Transnistria. Bucuresti: Editura Eminescu, 1995.

Novosolov Oleksandr, Polityka Rumunii shchodo ukrainskykh zemel u period dyktatury I. Antonesku (1940-1944 rr.): avtoreferat dysertatsiyi. Chernivtsi, 2008.

Odessa v Velikoj Otechestvennoj Vojne Sovetskogo Sojuza. Sbornik dokumentov i materialov. Tom 2. Odessa: Odesskoe oblastnoe izdatel'stvo, 1949-1951.

Petrencu A. Romania şi Basarabia in anni celui de-al doilea razboi mondial. Chişinău: Epigraf, 1999. 176 p.

Popp Nicolae, Transnistria. Încercare de monografie regională. In Biblioteca revistei “Moldova Nouă”, nr. 2, 1943, pp. 184-195.

Procesul mareşalului Antonescu. Documente, Vol. 3. ed. Marcel Dumitru Ciucă. Bucureşti: Editura Saeculum, 1998.

Schulte Th.J., The German Army and Nazi Policy in Occupied Russia. Oxford, 1989.

Shetnykov Vasil, Do pytannia pro vtraty sered tsyvilnoho naselennia na pivdni Ukrainy pid chas nimetskorumunskoi okupatsii 1941-1944 rr. (problema dzherel). Storinky voiennoi istorii Ukrainy: zbirnik naukovih statei. NAN Ukrainy, Institut istorii Ukrainy. Kyiv, 2005. Vyp. 9. Chast. 2, ss. 351-358.

Solovei Rodica, Activitatea Guvernamintului Transnistriei on domeniul social-economic şi cultural: 19 auq. 1941 - 29 ian. 1944. Iaşi, 2004, 238 p.

Tarnavskyi Igor, Administratyvnyi podil ta orhany upravlinnia na terytorii pivdenno-zakhidnoi Ukrainy za chasiv rumunskoi okupatsii. Istorychni i politychni doslidzhennia. Kyiv, 2010. № 3-4. ss. 210-216;

Terefera Natallya, Okupatsiinyi rezhym na terytorii “Transnistrii" ("Zadnistrovia") v roky fashystskoi okupatsii kraiu (1941-1944 rr.). Storinky voiennoi istorii Ukrainy: zbirnik naukovih statei. NAN Ukrainy, Institut istorii Ukrainy. Kyiv, 2006. Vyp. 10. Chast. 1, ss. 476-483.

Verenca 0., Administrația civilă română in Transnistria 1941-1944. Ediția a II-a îngrijită dr. Șerban Alexianu. București: Editura Vremea, 2000.

Werth Alexander, Un corespondent pe frontul de est. Bucureşti: Editura Politică, 1970. 
